\title{
MICHAEL PRAETORIUS'S VARIABLE OPINIONS ON PERFORMANCE
}

\author{
JEFFERY KITE-POWELL \\ The Florida State University College of Music, Tallahassee, Florida
}

\begin{abstract}
Izvleček: Razprava govori o Praetoriusovih obsežnih opisih izvajalske prakse, ki vključujejo tudi njegove razlage, po čem se dobra skladba loči od slabše, kako izbrati in v prostoru namestiti izvajalce ter katere izvajalske prakse so dopustne in katerih se je bolje izogibati. Njegov pristop niha med hvaljenjem ali priporočili in karanjem oziroma negodovanjem. Viri so navedeni $v$ angleškem prevodu in izvirniku, ob teh pa so predlagani načini, kako $v$ današnjem času za izvedbo pripraviti večzborsko skladbo. Navedeni so primeri nekaterih sodobnih posnetkov.
\end{abstract}

Ključne besede: tempo (hitro/počasi), dinamika (glasno/tiho), besedilo in harmonija, prstni redi, oznake za mero, Psalm 116

\begin{abstract}
This article presents Praetorius's wide-ranging opinions on performance practice, including what distinguishes a good composition from an inferior one, how performance forces are to be selected and deployed, and which performance practices are acceptable and which are to be avoided. His stance varies from laudatory and supportive to censorious and disapproving. These and other issues are presented in both English and the original German, and offer suggestions on how to orchestrate a polychoral work today, including reference to recorded media.
\end{abstract}

Keywords: tempo (fast/slow), dynamics (loud/ soft), text and harmony, fingering, time signatures, Psalm 116

There can be no question but that both volumes two and three of Syntagma musicum have been referred to for centuries, but perhaps the twentieth century has seen more extensive references to these important works than any previous century. The purpose of this study is to present a few instances of Praetorius's approach to how large-scale works might have been performed at princely courts with very large numbers of paid performers or at small village chapels with more modest means. In either case, he offered a viable solution for every situation. It is à propos to quote here from page $10(5 v)^{1}$ of Praetorius's introduction to volume three, as it states his goals in publishing it quite succinctly:

1 Praetorius does not actually start numbering pages consecutively with number 1 at the top until the conclusion of the sixteenth page of the Introduction. The title page of the volume has no number, nor does the reverse side of that page; the next page is numbered 2 at the bottom, but again, the reverse side has no number. This continues through page 8 (which is really page 15), and its reverse side (p. 16) has no number either. To confuse things further, Praetorius misnumbers page 6 in the Introduction as page 8 . Therefore, the page referred to here should be " $10 / 5 v$ ", 
The principal aspects of this third volume of Syntagma musicum are for the most part the author's own thoughts and innovations, observed and carefully noted from his organization of sundry electoral and princely musical concerts in various localities - applied to other concertos after further reflection and thought - and finally put to paper. ${ }^{2}$

His flexibility is manifest in the many words and phrases he employed to provide music directors with the options they needed when performing a large-scale musical work. In the course of this discussion the most commonly used of these - selected from among the nearly one hundred examples found in Syntagma musicum III alone - will be highlighted; words such as: "however you like," "whatever you wish," "wherever you please," "whenever you prefer," "whichever you choose" - or any combination of these and similar words (approve, decide, want, determine etc.).

But there are also other occasions on which Praetorius is not so flexible and is, in fact, quite adamant about how things should proceed. Indeed, he can be stingingly critical of musicians and intolerant of their actions. So these two opposing aspects will be presented separately in the following discussion. First, his willingness to give music directors choices.

\section{Performance Forces}

The following quotations demonstrate Praetorius's complete adaptability and utter lack of restraint when it comes to choosing instruments and deciding on instrumental choirs to use when performing a concerto, and how to deploy them in the church. He suggests that "it is likewise pleasing at times to hear the tenor in some compositions sung by a boy an octave higher". ${ }^{3}$ Or:

The sound will become even more resounding and splendorous if a great bass shawm, double curtal, or violone [...] - other instruments, too, if available - are added to the inner and upper parts. From every concerto one can select anywhere from one, two, or three such choirs - each one consisting of only four persons, more if possible - which are then placed in separate locations in the church. Depending on the situation, one can completely omit [a choir] if there is a shortage of performers, since this choir is an added choir [...], whose function is only to enrich and reinforce the music. ${ }^{4}$

because page $5 v$ is opposite page 8 in the facsimile, and 10 refers to the tenth page from the title page; this also conforms with the numbering used in the Guillotel-Nothmann transliteration.

2 "Alldieweil das fürnembste in diefem Dritten Tomo Syntagmatis Musici, meisten theils des Autoris eigene Gedancken unnd Inventiones seyn, welche er bey Anordnung unterschiedener Chur: und Fürstlichen Concert-Music an unterschiedenen Ortern sonderlich observiret und fleissig in acht genommen, auch durch weiteres nachsinnen unnd dencken in andern vielen Concerten ad usum transferiret, auch endlich auff- unnd zu Papier gesetzet." Praetorius, Syntagma musicum III, 10(5v). This and the following references to Syntagma musicum III are to the Kite-Powell translation. The original text can be found in Guillotel-Nothmann's transliteration (see references).

3 "Dergestalt denn auch bisweilen den Tenor gleicher massen in etlichen Cantionibus von eim Knaben in der Octav drüber singen zulassen, nicht unanmütig zuhören.” Praetorius, Syntagma musicum III, 162/158.

4 "Und wird solche Harmonia noch mehr erfüllet, und mit grösserer Pracht erweitert, wenn man 
There are a number of performance options here, the most striking of which is to recommend the use of a great bass shawm in one of the choirs. Shawms of any size were generally relegated to outdoor settings, mainly because of their penetrating sound. And just how many great bass shawms were readily available at courts and churches, anyway? Praetorius frequently suggests using consorts of instruments to substitute for a vocal choir, or simply to enhance and enrich the overall sound, and several options are offered in this quotation, including having even more than four instrumentalists in any of the choirs, or simply omitting one of the choirs entirely for lack of personnel. Assigning the choirs to various locations in the church also gives the director more choices in his effort to balance the choirs and their overall sound in the church.

And in this quotation he explains why one instrumental group is preferred to another:

[...] I have called this capella "fidicinia," because it is better to form the group with stringed instruments such as violins, lutes, harps, and all others, particularly violas da gamba (if available, but violins when_they are lacking) for the sound and sonority of the viols and violins is continuous, especially charming, and free of breathing, which cannot be dispensed with on sackbuts and other wind instruments. For_variety, however, one can sometimes use four sackbuts, $[. .$.$] or three sackbuts and a tenor recorder,$ or a cornett on the discant, or else a curtal and three recorders. ${ }^{5}$

Here, Praetorius makes it abundantly clear that he prefers the viola da gamba instrumental group to the violin family, but he would choose violins over wind instruments due to their continuous sound, as opposed to that of wind instruments, whose sound is interrupted by the breathing of the performers. This issue returns in another reference to instrumentalists having to breathe cited below. When it comes to wind instruments, however, his favourite was by far the sackbut (also obvious from this quotation): for instance, using four sackbuts, or three sackbuts with a treble instrument on the discant line (tenor recorder / cornett), or using a bass curtal on the bass line and recorders on the other lines.

dabey einen grossen BaßPommer, doppeltFagott, oder grosse BaßGeygen (Italis, Violone) Auch wol andere Instrumenta, wo deren uberig verhanden, zu den Mitteln und OberStimmen ordnet. Solche Capellen aber können unterschiedlich, eine, zwo oder drey aus einem jeden Concert heraus gezogen, ein jede insonderheit nur mit vier oder mehr Personen, wenn man die haben kan, besetzt, und an abgesonderte örther in der Kirchen gestellet, Auch in mangelung der Personen, gestalten Sachen nach, gantz und gar außgelassen werden. Dieweil diese Capella fast als die Ripieni, allein zur erfüllung und besterckung der Music, ein aus den ander Choren extrahiret und heraus gezogen ist." Praetorius, Syntagma musicum III, 124/133[113].

5 “[...] Daß ich diese Capellam darumb, Fidiciniam genennet, dieweil es besser ist, mit Besäiteten Instrumenten, als Geigen, Lauten, Harffen und allen andern, und sonderlich mit Violn de Gamba, wo man die haben kan, In mangelung aber derselben, mit Violen de Bracio, dieselbige Capellam zu bestellen. Denn der Sonus und Harmonia der Violen und Geigen continuiret sich immer nach einander mit sonderbahrer Liebligkeit, ohne einige respiration, deren man uff Posaunen und andern blasenden Instrumenten nicht entrathen kan. Jedoch pro variatione kan man bißweilen 4 Posaunen, Do denn nicht irret, daß der Cantus in etlichen Octava inferiore uff der Posaune musiciret werde. Oder 3 Posaunen, und eine Tenorflöite, oder ein Cornett zum Discant, oder aber einen Fagott, und 3 Flöiten zur umbwechselung darzu gebrauchen.” Praetorius, Syntagma musicum III, 127/136[116]. 
Praetorius talks about the choir director using his discretion when considering how to distribute his resources. In many cases it is simply not possible to realize the work as Praetorius described it; but for him, the important thing was that it be performed, regardless of the performing forces to hand.

In this regard, Praetorius asserts that the quality of the solo voice is paramount, as seen in this quotation:

The whole essence of the intended work lies in the solo voices, whose parts must be sung and enunciated clearly [...] these works can be performed entirely by these singers alone with organ or regal accompaniment and without the other vocal or instrumental ensembles, especially since such groups are not available everywhere. For this reason one must select the best singers for these parts, ones who are not only secure, dependable, and unconstrained, but who are also able to sing in the current new manner with elegance and a good disposition. ${ }^{6}$

He then bemoans the fact that:

At present, however, such singers are found only in a few places in Germany. Still, one often finds among students and in schools a number of pure, pleasing, and fresh voices, which are every bit as pleasant to listen to as others who dare to use many diminutions and passaggi indiscriminately and with a lack of judgment. ${ }^{7}$

And finally, notwithstanding the fact that there are many more references concerning performance forces in his theoretical output, ${ }^{8}$ this one expresses a self-deprecation similar to others scattered throughout his writings.

Although I could have been somewhat more detailed in my discussion of the various ways a concerted piece might be arranged - by varying the instrumentation and otherwise - I have however thought it over some more. Music has reached such heights these days

6 "Und dieweil nun in allen diesen Arten und Manieren, totum negotium, das gantze unnd vornembste Werck, uff den Concertat-Stimmen, das seind die Stimmen so gesungen und wol pronunciret werden müssen, bestehet [...] Denn solche Concert und Cantiones mit denselben Stimmen gantz allein, ohne zuthun der andern Vocal-Capellen oder Instrumenten (bevorab weil die nicht allenthalben vorhanden) in eine Orgel oder Regal volnkömlich musicirt werden können. Darumb muß man zu diesen Stimmen die besten Cantores und Sänger außlesen, die nicht allein secur, gewiß unnd freymütig seyn, sondern auch auff die jetzige Newe Manier und weise, gratia mente und mit guter Disposition singen können." Praetorius, Syntagma musicum III, 193/196.

7 "Jedoch weil solche Cantores unnd Sänger, bey uns in Teutschland, noch zurzeit an wenig Ortern vorhanden, So findet man gleichwol unter den Studiosis und in Schulen, offtmals etliche feine reine, artige und frische Stimmen, welche ja so anmütig zu hören seyn, als offtmals andere, die viel diminuirens als passaghyrens, ohn unterscheid und absque judicio zu machen, sich unterstehen wollen." Praetorius, Syntagma musicum III, 194/196.

8 In Syntagma musicum III, chapters 7 and 8, Praetorius provides detailed information on the use of instruments and vocal and instrumental choirs, as well as countless suggestions on how and where combinations may be possible, and recommendations on the placement of the performance forces. 
that even in our country there are outstanding musicians who have not only had quite magnificent German and Latin concertos and songs published, but who themselves know how to arrange and direct such multi-choir works better than I can explain or bring to light with my humble abilities. ${ }^{9}$

\section{Performance Practice}

With regard to performance practice, the concept of varying the tempo in the performance of a motet or madrigal is generally not thought of as appropriate by many conductors today, but Praetorius felt it imperative to be flexible with the tempo in such works. Here is his comment concerning this:

Some people are unwilling to allow the intermingling of the motet and madrigal styles in the composition of any musical works. I do not share this opinion, however, as in motets and concertos there is a special charm and delightfulness when several quite expressive and slow measures at the beginning are followed by several quick phrases, and then once again slow and stately passages alternate with faster ones. In this way it will not proceed in a constant monotonous fashion, but with an alternating slow and fast pace as well as with great attention being given to crescendos and very soft sounds $\left[\ldots . . .^{10}\right.$

Here is another, similar reference:

Often the composition itself, as well as the text and the meaning of the words, necessitates that the beat now and then, but not too frequently, accelerates and slows down, and also that the choir resonates softly and gently at times and firmly and lively at other times; no doubt greater restraint will be necessary in the church than at table with such alternations. ${ }^{11}$

9 “Ob ich zwar etwas weitläufftiger hette uffzeichnen können, wie und welcher gestalt ein jeder ConcertGesang auff etlich sondere Maniere mit variirung der Instrumenten und sonsten anzuordnen, So habe ich es doch noch zur zeit bedencken getragen. Dieweil die Music so gar hoch gestiegen, daß numehr vortreffliche Musici auch Germania nostra patria gefunden werden, welche nicht allein gar herrliche liebliche deutsche unnd Concert und Cantiones in öffentlichem druck herfür kommen lassen, besondern auch selbsten solche und Lateinische dergleichen Concert per Choros besser anzuordnen und dirigiren wissen, als ich es nach meiner wenigkeit vorschreiben oder an den Tag geben kan.” Praetorius, Syntagma musicum III, 156/152.

10 "Ettlliche wollen nicht zu geben, daß man in compositione alicuius zugleich Motettische und Madrigalische Art untereinander vermischen solle. Deroselben Meynung ich mir aber nicht gefallen lasse, Sintemahle es und Concerten eine besondere lieblichkeit unnd anmütigkeit gibt unnd conciliiret, wenn im anfang etliche viel Tempora gar pathetisch und langsamb gesetzet seyn, hernach etliche geschwinde Clausulen daruff folgen, Bald wieder umb langsam und gravitetisch, bald abermahl geschwindere umbwechselung mit einmischen, damit es nicht allezeit in Tono und Sono fortgehe, sondern solche und dergleichen verenderungen mit eim langsamen und geschwinden Tact. So wol auch mit erhebung der Stimmen, unnd dann bißweilen mit gar stillem Laut mit allem fleiß in acht genommen werde, wie kurtz vorher angezeiget worden." Praetorius, Syntagma musicum III, 92/80.

11 "Es erfordert aber solches offtermahls die composition, so wol der Text und Verstand der 
He further states:

It therefore does not appear to be such a bad idea to use the $\mathrm{C}$ signature for motets and other sacred works with many black notes, so that the tempo may be somewhat slower and more solemn [...] But everyone can decide such matters for himself, based on the text and harmony, where a slower or faster tempo must be taken. ${ }^{12}$

It cannot be ascertained conclusively just how much Praetorius's consideration of "text and harmony," "slower and faster" and "softer and louder" were influenced by his fellow countrymen as represented by their compositions and theoretical treatises - including his uncle, Christoph Praetorius (1574), Cyriakus Schneegass (1571), Georg Quitschreiber (1598/1601), Seth Calvisius (1602) or even Daniel Friderici (1618). One could further surmise that he benefited from the large quantities of compositions and treatises in his possession that were written by well-known Italians, such as Claudio Monteverdi's stile moderno or seconda prattica laid out in his fifth book of madrigals in 1605, or Lodovico Viadana's concept of thoroughbass demonstrated in his Cento concerti con il basso continuo, 1602, or even Agostino Agazzari's treatise of 1607 (Del sonare sopra 'l basso con tutti li stromenti e dell'usu loro nel conserto), from which Praetorius quotes extensively - all of these theorists/composers surely must have shaped his thinking.

A most remarkable reference with regard to performance practice is Praetorius's quotation from Quitschreiber's 1598 treatise entitled De canendi elegantia:

Furthermore, it is not very praiseworthy and pleasing when singers, organists, and other instrumentalists from the town musicians hasten in the usual manner immediately from the penultimate to the final note of any composition without any hesitation. Therefore, I believe I must here admonish those who thus far have not observed this practice at the princely courts and in other well situated musical choirs to remain singing on the penultimate note somewhat longer, no matter what type or value it is, dwelling for four, five, or six beats, and afterwards they should close precisely on the final note. As the composition is brought to a conclusion, all the remaining voices should stop simultaneously, according to the desire and sign of the conductor or choirmaster. Nor should the tenors, a fifth above the bass or foundation pitch (the interval on which most tenor endings are set), lengthen their tone into a long after the bass is silent. But

Wörter an ihm selbsten, daß man bißweilen, nicht aber zu offt oder gar zu viel, den Tact bald geschwind, bald wiederumb langsam führe, auch den Chor bald stille und sanfft, bald starck und frisch resoniren lasse. Wiewol in solchen und dergleichen umbwechselungen, in Kirchen viel mehr, alß vor der Taffel eine moderation zugebrauchen vonnöten sein will." Praetorius, Syntagma musicum III, 92/80.

12 "Darumb deuchtet mich nicht ubel gethan seyn, wenn man die Motecten, und andere geistliche Gesänge, welche mit vielen schwartzen Noten gesetzt seyn, mit diesem Signo C zeichnet, anzuzeigen, daß alßdann der Tact etwas langsamer und gravitetischer müsse gehalten werden. Es kan aber ein jeder den Sachen selbsten nachdencken, und ex consideratione Textus et Harmoniæ observiren, wo ein langsamer oder geschwinder Tact gehalten werden müsse." Praetorius, Syntagma musicum III, 70/50-51. 
if the bass lengthens its tone a little longer, for two or four beats, it lends ornament and grace to the composition, which no one can deny. Georg Quitschreiber. ${ }^{13}$

It is relatively common knowledge that whenever a theorist wrote about a subject, he was describing something that had been in existence for quite some time - months, years or even decades - as observed in several earlier treatises, including a few of the ones mentioned above. It is not easy to know just how widely disseminated and well-known Quitschreiber's eighteen rules for singing were in 1598, but the practice he is describing in this passage was promulgated far and wide twenty years later through Praetorius's citation of it in Syntagma musicum III in 1619.

\section{Practical Examples Regarding Performance Practice}

The audio examples found in the YouTube references cited below demonstrate just some of the ways in which a music director might have orchestrated a composition in the early seventeenth century, and how it might have been interpreted. The first example was composed by Praetorius and is a setting of Psalm 116, "Das ist mir lieb", found in a collection of sixteen works all based on the same text that were commissioned by the wealthy merchant Burckhard Grossmann in 1616 and published in 1623, two years after Praetorius's death (and a work that he recognized would be his final composition). All of the works call for a five-voice choir and many of them are divided into as many as seven parts, some of which reduce the number of voices to as few as three. Praetorius's setting is the sole arrangement that includes instrumental sinfonias, whose purpose is to introduce each of the three sections into which the work is divided. In his Ordinantz (Performance Instructions) he suggests that these can be omitted, if necessary, for lack of performers. ${ }^{14}$ The choir is divided into a small group, often referred to by the Latin word voce, which alternates with a larger tutti group. The same result comes from his use of $\boldsymbol{p}$ and $\boldsymbol{f}$ for the softer or louder passages. And here again, he suggests in the Ordinantz that instruments can replace voices in the soft sections. ${ }^{15}$ At least one recorded performance of this composition substitutes instruments in the places that are marked piano. ${ }^{16}$

13 "Præterea cùm non admodum plausibile et gratum, quando Cantores, Organicines et alii Instrumentales Musici Oppidani pro more consueto statim ex penultima cujusque Cantionis Nota, in finalem ultimam sine morula aliqua deproperant, monendos hîc esse puto, qui adhuc ex Principum aulis et aliis benè constitutis Choris Musicis hoc non observarunt, diutius aliquantum in penultima, qualis quantaque etiam illa sit, commorati in quartum, quintum vel Sextum usque Tactum canendo consistant, et de hinc in ultima demum desinant. Cantione ad finem deductâ, reliquæ voces omnes ad voluntatem et nutum Directoris vel Chori præfecti pariter consilescant, nec Tenoristæ in Quinta supra Bassum vel fundamentum (in qua ut plurimùm finis Tenori constituitur) vocem suam in longum, silente Basso protrahant. Sed si Bassus per duo vel quatuor Tactus longiusculè protrahatur, ornamentum et gtatiam Cantilenæ conciliari, nemo est qui negare possit. Georg Quitschreiber.” Praetorius, Syntagma musicum III, 92/80.

${ }_{14}$ See point no. 6 in the Appendix below.

${ }^{15}$ See point no. 7 in the Appendix below.

${ }^{16}$ See Bibliography, section Sound. Dynamic indications on page 2 of the Music example. 


\section{Music example}

First and last pages of Michael Praetorius's Ps. 116; "Das ist mir lieb" (Grossmann, Anguish, 39, 57)

\section{[4.] Michael Praetorius}

Part 1
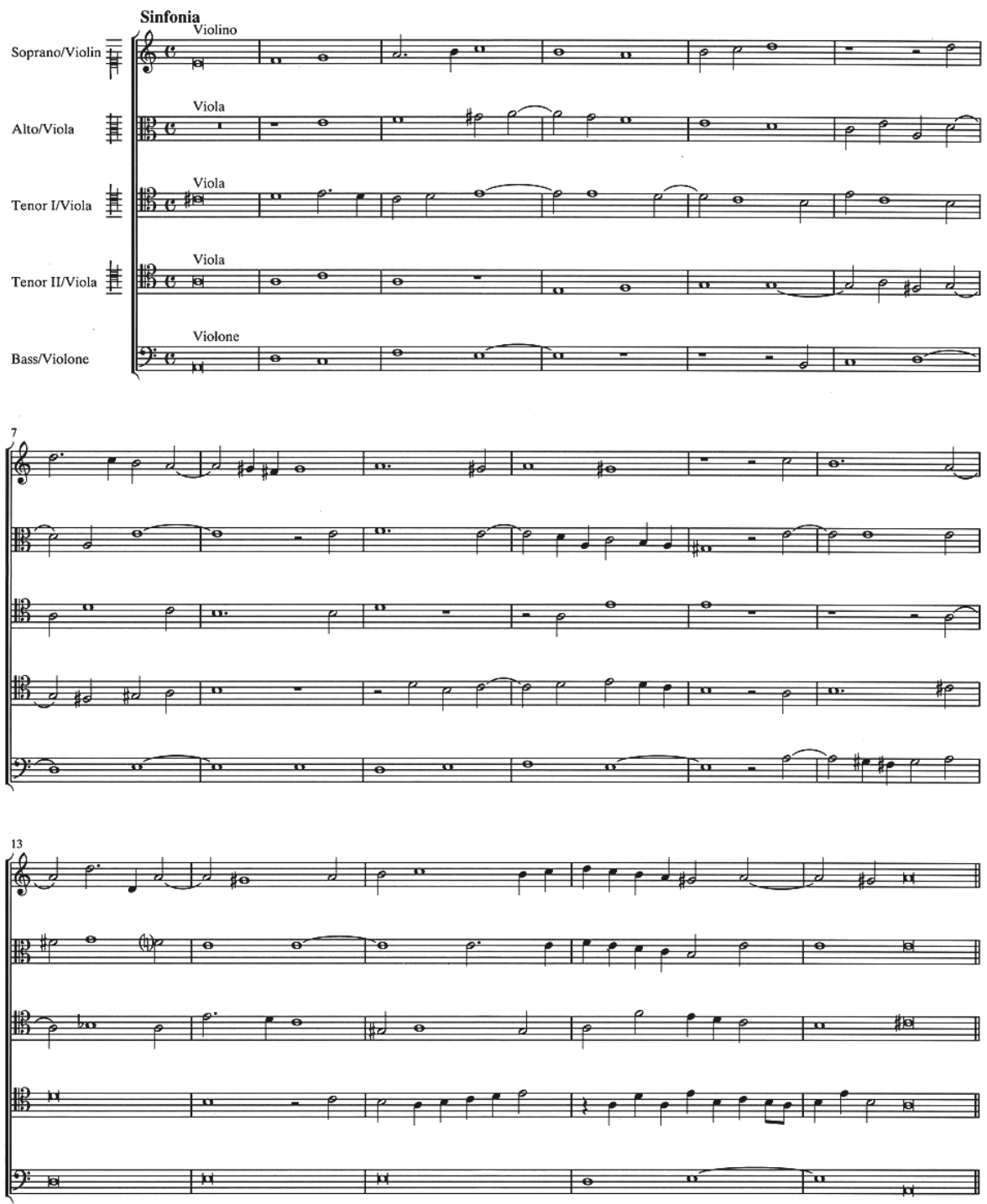


\section{Music example}

(continued)
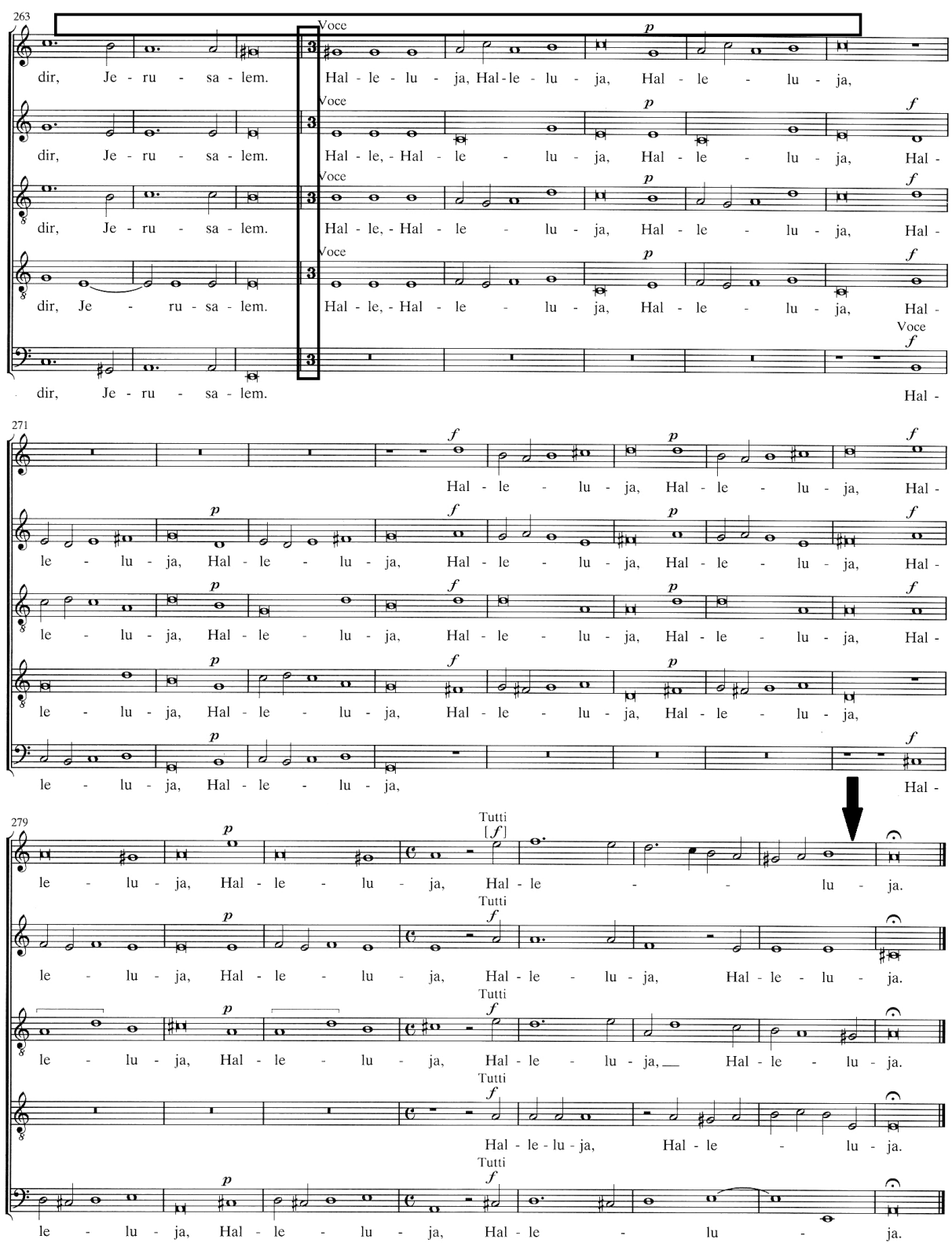
In the first audio example ${ }^{17}$ the opening sinfonia is played by a consort of violas da gamba and continuo organ; it is then repeated - something not indicated in the score with the addition of three sackbuts, two curtals and a regal: again, the type of approach Praetorius suggests in the Ordinantz. ${ }^{18}$ In addition, Praetorius's advice to alternate slow tempos with more animated ones and softer passages with more forceful ones - all based on the accompanying text or on his forte/pian indications in the score - has been followed. At the end of each of the recordings listed here, special attention should be given to the penultimate chord of the composition. Except for the Florida State University version, it is safe to assume that there have been no performances, either live or recorded, that have adhered to Praetorius's admonition to extend the penultimate beat by four to six counts.

In the next sound example ${ }^{19}$ the sinfonia is not repeated. It is played by an ensemble of strings - two violins, two violas, violoncello, bass viola da gamba, theorbo and organ. This group frequently functions as the smaller choir in alternation with the vocal choir, which they also double.

In the final audio example ${ }^{20}$ the opening sinfonia is repeated, but with the same instrumentation both times, strings with cornett on the discant. The vocal choir sings $a$ cappella at times and is accompanied on other occasions.

\section{Issues Concerning Time Signatures}

In addition to Praetorius, eight other composers in this collection used modern time signatures, but seven resorted to signatures indicating mensurations in common use in the sixteenth century, a practice that Praetorius rails against in this quotation: ${ }^{21}$

${ }^{17}$ To listen to this example, which was posted on YouTube on 10 March 2013 and accessed on 23 Aug. 2019, type "Das ist mir lieb by Michael Praetorius" into a YouTube search window and select the performing group directed by Jeffery Kite-Powell (Cantores Musicæ Antiquæ). The opening (page 39 in the example above) plays from counter number 0-224; the concluding page (page 57 in the example above) begins at counter number 17:04.

${ }_{18}$ See point no. 1 in the Appendix abowe.

19 To listen to this example,which was posted on 11 June 2018 and accessed on 23 Aug. 2019, type "Das ist mir lieb by Michael Praetorius" into a YouTube search window and select the performing group Rheinische Kantorei directed by Ezard Burchards. The opening (page 39 in the example above) plays from counter number 0-106; the concluding page (page 57 in the example above) begins at counter number 13:50.

${ }^{20}$ To listen to this example, which was posted on 24 Feb. 2015 and accessed on 23 Aug. 2019, type "Das ist mir lieb by Michael Praetorius" into a YouTube search window and select the performing group directed by Paul van Nevel (the Huelgas Ensemble). The opening (page 39 in the example above) plays from counter number $0-141$; the concluding page (page 57 in the example above) begins at counter number 14:44.

${ }^{21}$ For all of his ranting, Praetorius is himself not immune from using outmoded time signatures, as seen in many of his own compositions (see Syntagma musicum III, 74n41 of my translation) and several works in the Polyhymnia caduceatrix et panegyrica (among others, no. 37: "Ach mein Herr, straff mich doch nicht"). See also his discussion on metre in chapter 7, pages $67 \mathrm{ff}$ of Syntagma musicum III - especially pages 76-83, on which he provides music examples with different time signatures in each part. 
But I certainly see that many [musicians] do not observe their own precepts concerning these very matters and indiscriminately make use of one [signature] for another. Wherefore lest they should hinder the students and singers with superfluous matters, all the signatures indicated above [72/52], and made use of by the most famous musicians to this very hour, must be removed and destroyed entirely from the musical writing tablets (inasmuch as these signatures demonstrate nothing, and are not absolutely necessary and useful, but on the contrary produce only difficult intricacies). ${ }^{22}$ [SM III: 73/53])

Further evidence of Praetorius's rejection of strict interpretations of established norms is expressed in this well-known response to the use of a certain prescribed keyboard fingering.

Some people have special opinions about these things and are wont to scorn organists who do not follow this, that, or the other method of fingering; this, however, in my opinion, is not worthy of discussion. Let him run up and down the keyboard using his fingertips, middle joints, or the back side of his fingers - even his nose, if that could help - as long as he brings a pure, correct, and pleasing sound to the ear. It matters not by what means he accomplishes it. ${ }^{23}$

In addition to Hans Buchner's example of fingering in his Fundamentum from 1551, published posthumously, and Elias Ammerbach's rules and exercises for fingering (1583), there are several other sources from Germany and other European countries that discuss fingering. ${ }^{24}$ Praetorius's remark dismissing established norms is therefore quite unusual.

\section{Humility Revisited}

Another example of Praetorius being humble is found in this quotation:

In my humble opinion one should not forget to use mordents and tremoletti in the absence of divisions or other similar runs, as they are not nearly as disconcerting to the singer, or a little less anyway, as a profusion of runs and divisions would be. But

22 "Verum tamen plurimos sua ipsorum præcepta non observare, et indiscretè unum pro altero usurpare vîdeo. Quapropter ne superfluis remorentur discentium et canentium animi, omnia in principio exhibita Signa, à Musicis etiam præclarissimis ad hanc usque horam usurpata (ut potè nihil, nisi non usque adeò necessarias et utiles, imò intricatas difficultates exhibentia) è tabulis Musicis prorsus tollenda et removenda." Praetorius, Syntagma musicum III, 73/53.

23 "Wie dann ihrer viel sich auch damit etwas sonderliches bedüncken lassen / vnnd daher etliche Organisten / wegen dessen / daß sie nicht dieser oder jener Application mit den Fingern sich gebrauchen / verachten wollen. Welches aber meines erachtens der Rede nicht wert ist: denn es lauffe einer mit den foddern / mitten / oder hinder Fingern hinab oder herauff / ja / wenn er auch mit der Nasen darzu helfen kondt / vnd machte vnd brechte alles fein rein just vnd anmutig ins Gehör / so ist nicht groß dran gelegen / Wie oder vff was maß vnd weise er solches zu wege bringe." Praetorius, Syntagma musicum II, 44.

${ }^{24}$ Lindley, "Fingering 1". 
no one should further impose his prejudice on anything here; instead, everyone is free to do as he likes. ${ }^{25}$

Praetorius prefers a less active approach to ornamentation than that achieved through florid runs and figurations, regarding the former as less distracting to the singer. Nevertheless, he insists that the performer should be allowed to incorporate whatever ornamentation he or she chooses.

\section{Complaints Regarding Aspects of Performance}

Praetorius can be rather caustic in his comments when he disagrees with something or believes there is a better way. More specifically, when it comes to inappropriate sounds, Praetorius shows himself especially critical in these three remarks:

But since such low notes sound unpleasant, almost like a cow-horn, and since violins do not produce a good sound on $\mathrm{g}$, their lowest string, I think it is far better and more graceful, as just mentioned, to use a sackbut or viola in such cases. ${ }^{26}$

And:

A tremendous nuisance and racket are created, however, if the instrumentalists tune their curtals, sackbuts, and cornetts during the organist's prelude and honk a lot on the reeds and cause commotion so that one's ears hurt as a result and it makes one shudder.

It sounds so awful and makes such a confusing din that one does not know whether one is coming or going. ${ }^{27}$

This stinging comment refers to instrumentalists:

When several instruments are present in an ensemble they must watch each other and

25 "Wie dann auch meines wenigen erachtens, do ja keine einige Diminutiones oder andere dergleichen Movimenten gebraucht werden, der Mordanten oder Tremoletten nicht aller dinge zu vergessen. Sintemal des Concentores oder Vocalisten Stimme hierdurch ganz nicht, oder ja so sehr nicht, als wol durch vielerley Coloraturen und Diminutiones interturbiret werden kan. Doch sol hinfort niemand nicht zum præjudicio vorgeschrieben seyn, sondern wird eim jeden, wie ers damit halten wil, frey gelassen.” Praetorius, Syntagma musicum III, 144/137.

26 "Weil es aber in solcher tieff kein gratiam, sondern fast einem Kühhorn gleich klinget, Die Discantgeigen auch nur biß ins g, und uff der selben untersten Säiten keine rechte Harmoniam von sich geben, So erachte ichs, wie jetzt gedacht, das ein Posaun oder Tenorgeig ungleich besser und Anmüthiger darzu zugebrauchen sey.” Praetorius, Syntagma musicum III, 159/155.

27 "Ein aus dermassen aber sehr grosser Ubelstand und Klang ist es, daß, wenn der Organist præambuliret, die Instrumentisten in mittelst ihre Fagotten, Posaunen und Zincken anstimmen, und viel fistulirens und wesens durcheinander machen, daß einem die Ohren darvon weh thun, und die kalten Schnuppe bekommen möchte. Sintemal es so ubel lautet, und ein rumor durcheinander machet, daß man nicht weiß, obs gestochen oder gehawen ist." Praetorius, Syntagma musicum III, 156/152. 
leave enough room to prevent bumping into each other, so to speak; instead, when there are many of them, each must wait his turn to display, one after another, his schertzi, trilli, and accenti. They must not warble among themselves like a flock of sparrows, each trying to shriek and crow the highest and loudest to prove himself the cock of the roost - something to be carefully observed with treble violins and cornets. ${ }^{28}$

\section{The following comment concerns both instrumentalists and singers:}

In concertos it is this point above all others that must be kept diligently in mind by all instrumentalists and singers, so that no one covers up and outshouts anyone else with his instrument or voice; this is all too common and results in a great deal of splendid music being thoroughly spoiled and ruined. When one always wants to be heard above another - instrumentalists, especially the blaring cornetts, but also the shrieking singers - the pitch ultimately goes up so high that the organist, if he is playing, must cease altogether, and in the end the entire choir finds that it has gone a half step sharp, indeed sometimes a whole step, because of this excessive blaring and screaming.

Doubtless it was this that Agazzari saw when he said he wants wind instruments "especially the cornetts" due to the variation caused by human breathing, to refrain from playing in soft, pleasing consorts; they should only be mixed in with large ensembles when the music is noisy. The sackbut can, however, be used occasionally in small ensembles as the bass to a small positive or four-foot organ stop, if blown well and gently. ${ }^{29}$

But he hastens to add that: "This does not include the excellent cornettist and similar instrumentalist who can control and master his instrument". ${ }^{30}$

28 "Wenn aber Gesellschaft und andere mehr Instrument verhanden seyn, müssen sie eins uffs ander sehen, ihnen untereinander raum ond platz geben, nich gegen einander gleichsam stossen, sondern wenn ihrer viel seyn, ein jedes seiner zeit erwarten, biß daß die Reye, seine Schertzi, Trilli und Accent zu erweisen, auch an ihn komme. Und nicht, wie ein hauffen Sperlinge untereinander zwitzschern, und welches nur zum höchsten und stärcksten schreyen unnd krehen kan, der beste Hahn im Korbe sey. Welches dann bey DiscantGeigen, Cornetten, \&c. eben so wol zu observiren." Praetorius, Syntagma musicum III, 151/148.

29 "Und dieser Punct ist vor allen dingen in eim jeden Concert auffs allerfleissigste von allerley Instrumentisten, so wol auch von Vocalisten und Sängern in acht zu nehmen. Damit nicht einer dem andern mit seinem Instrument oder Stimme ubersetze und uberschreye. Welches dann gar sehr gebräuchlich, und viele herrliche Music dadurch in grund verdorben und zerstöret wird. In dem sich immer einer vor dem andern will hören lassen, also, daß die Instrumentisten, sonderlich uff den Cornetten mit ihren uberblasen, und auch die Sänger mit hrer Vociferation und uberruffen, endlich so hoch in die höhe kommen, daß der Organist, wenn er mitschlägt, gantz und gar auffhören muß und in Final sich befindet, daß der gantze Chor durch deroselben ubermessiges uberblasen und uberschreyen, und ein halben, ja offt umb ein gantzen Thon, und mehr in die Höhe gezogen. Dahinn denn ohn allen zweiffel der Augustinus Aggazarius gesehen. In dem er will, daß die blasende Instrumenta, wegen der verenderung, so des Menschen Athem darinnen verursacht, und sonderlich die Zincken, nicht in stillen, guten unnd lieblichen, sondern allein in grossen, rauschenden Music mit untergemenget und gebrauchet werden sollen. Bißweilen aber könne man auch in kleinen Music die Posaun, wenn sie wol und lieblich geblasen, bey den kleinen Positiflin oder Orgelstimmen von 4 Fußthon, zum Baß gebrauchen.” Praetorius, Syntagma musicum III, 153/149.

30 "Welcher aber seinen Zincken, und dergleichen Instrumenta recht zwingen und moderiren kan, 
Regarding certain types of polyphonic compositions, Praetorius has this to say:

Anyway, this style has no real joy and charm, for when all voices are sung, one hears neither period nor sentence, due to the interruptions caused by the constant repetition of the imitations, and because each voice sings separate and different words at the same time which does not please discerning people who are paying attention to this. ${ }^{31}$

\section{Suggestions Regarding Accompaniment}

On accompanying boys, Praetorius remarks:

When the organist is accompanying the boy assigned to him, it is necessary for him to use the softest and most delicate eight-foot gedackt in the Rückpositiv or in the Oberwerk and play along with the boy at a very slow tempo. When the full ensemble enters, however, he can use a more penetrating stop in the great organ or the positive and avoid the full organ (as some would like, so that the other choral and instrumental ensembles are not drowned out). ${ }^{32}$

\section{And this:}

Here the voices or choirs respond to each other or alternate with one another in the manner of an echo - forte \& pian, loud and soft - which sounds most agreeable in chambers. In large churches, however, it is not so satisfactory, since those not seated near the performers may not hear the pian and soft echo at all, or perhaps only slightly. It is especially the organist who must keep things within bounds in his accompaniment either by not playing at all or by playing only the bass without the inner parts. He must display great subtlety at the keyboard, so that the soft voices may be heard and not be drowned out by the organ or regal. ${ }^{33}$

und seines Instruments ein Meister ist, sol hiermit nicht gemeint seyn.” Praetorius, Syntagma musicum III, 153/149.

31 "Darnach auch, Weil sie keine rechte art Lust- und annemligkeit haben. Denn wenn alle Stimmen gesungen werden, so höret man weder Periodum noch sensum, weil alles von den Fugen, Welche sich so offt repetiren interrumpiert wird, und eine jede Stimme besondere und unterschiedliche Wort, zu einer zeit singet und aus spricht, welches verstendigen Leuten, die darauff mercken, mißfelt." Praetorius, Syntagma musicum III, 154/150.

32 "Es ist aber nötig, daß der Organist, wann der eine Knab zu ihm geordnet wird, daß stilleste und sanffteste Gedact-Register auff 8 Fuß Thon, im Rück-Positiff oder im Ober-Wercke ziehe, und mit demselben Knaben, auff einen gar langsamen Tact zugleich intonire. Wenn aber der Plenus Chorus einfelt, so kann er im Werck oder aber im Positiff ein schärffer Register, doch gleichwol nicht das volle Werck (wie etliche wollen, damit es die andern Choros der Vocalisten und Instrumentisten nicht uberschreye und ubertäube) gebrauchen." Praetorius, Syntagma musicum III, 176/173.

33 "Stimmen oder Chori sich selbsten oder aber per vices in art eines Echo, forte et Pian, starck und still respondiren. Welches in Gemächern sehr lieblich und anmütig zu hören. In grossen Kirchen aber wil es sich so wol nicht thun lassen, sintemal die jenige, so nicht nahe bey den Musicis stehen, das Pian unnd stille Echo gar nicht, oder doch fast wenig vernemen können. Darumb dann auch sonderlich der Organist so mit einschlegt, sich hierinn sehr moderiren, und entweder 


\section{Reflections on the State of Music}

And finally, on page two of his Introduction to Syntagma musicum III, Praetorius offers this grandiose encomium on the state of music in his time:

In this third volume and the following fourth volume I have written about matters of prime importance that the Kapellmeister, singing teacher, and practical musician will need to know, especially at the present time in which music has ascended so high that it is practically impossible to imagine that it could achieve greater heights. ${ }^{34}$

This, of course, is not a new phenomenon, as prominent composers of earlier centuries - particularly Philippe de Vitry and Guillaume DuFay, as well as his contemporary Claudio Monteverdi - considered the music of their time as superior to that of previous eras.

For the music world, Praetorius is indisputably one of the most important and prominent polymaths to ever grace our field. Despite his oft-stated humility, he expected his fellow music directors to come to the same conclusions as he, as illustrated in his remark that "[...] any sensible musician willing to reflect on these matters further is most likely to approve and agree with me in this case". ${ }^{35}$

His impact is as undeniable as it is lasting.

gar nicht oder aber nur den $\mathrm{Ba} \beta$ ohne Mittel-stimmen darzu schlagen, und gar subtiel uber den Clavem herwischen und greiffen muß, darmit die stille Stimmen vernommen, gehört und von der Orgel oder Regal nicht uberteubet werden mögen." Praetorius, Syntagma musicum III, 192/195.

34 "So hab ich nun in diesem Tertio und folgendem Quarto Tomo, das fürnembste so einem Capellmeister Phonasco und Musico Practico, Sonderlich jetziger zeit, da die Music so hoch gestiegen, das fast nicht zu gleuben, dieselbe numehr höher werde kommen können, zu wissen von nöhten sein wird, begriffen und verfasset." Praetorius, Syntagma musicum III, 4/2v.

35 “[...] ein jeder verständiger Musicus, der den Sachen etwas weiter nachdencken wil, gar wol approbiren, und dißfalls mit mir einig wird”. Praetorius, Syntagma musicum III, 108/96. 


\section{Appendix}

Burckhard Grossmann writes that he published these instructions in exactly the form in which Praetorius submitted them: ${ }^{36}$

The late author Herr Praetorius, in transmitting this psalm, also provided a detailed Ordinantz and several variations indicating how he wanted the same performed; he also sent me a most moving and ingenious letter in which he writes that he composed this psalm not only in friendly compliance with my Christian request, but also as his own farewell and thereby wanted to take his leave. Inasmuch as he passed away shortly thereafter and was transported to the heavenly Capelle, and after this work presumably composed not a note more, I have neglected neither this, his final farewell and swansong, nor to his ever praiseworthy memory and in dutiful gratitude, his Ordinantz, which I should have caused to be printed here, just as he sent it to me in his own hand.

\section{Ordinantz}

[Performance Instructions]

1. This 116 Psalm is firstly intended to be sung by five voices alone. It can further be performed with five additional instrumental parts; and thus there will be ten parts.

2. The instruments may be placed either with the singers or apart from them. If they are placed with the singers, they are to play only at the places labeled violino, viola, violone, and tutti. For everything else, labeled voce and performed by the singers alone, they must rest.

3. If, however, they are placed in a separate location, one must prepare five extra parts for the instrumentalists and write out from the five concertato parts the sinfonias along with those parts labeled violino, viola, violone, and tutti. But in place of the remainder, where the singers sing alone, labeled voce, write out the same number of rests. And thus a concerto for two choirs in ten parts will result; and in the absence of instrumentalists, this latter choir can be performed by singers, and the sinfonias either played on a regal [reed organ] or left out.

4. One can also write out pro capella plena yet another choir from the places labeled tutti; the music will thereby be markedly strengthened. And thus it will become a concerto for three choirs in fifteen parts. But this capella must be placed in a separate location, apart from the other choirs.

5. Above all else one must keep a slow and grave beat, so that the decorum of the text and movement of the affectum may be better observed and expressed.

6. The sinfonias before each of the three parts must be played by viols and other instruments. But if the instruments are not available, one can play the sinfonias of a regal or harpsichord, also the places labeled violino, viola, etc. But if neither regal or harpsichord is available, all the sinfonias must be left out and the Psalm sung by the singers alone.

7. In the third part there is an echo, and it can be performed in two different ways. 1. At the word forte one must sing with a strong and bright voice; at pian, with a loving and gentle voice; with instruments remaining out. 2 . One can also sing the parts marked forte purely vocally; but have those marked pian played by instruments alone without voices. And thus an elegant variation will result, one not altogether unpleasant to hear.

${ }^{36}$ Burckhard Grossmann, Anguish of Hell, $18-19$ in prefatory material, plates IX \& X in the Quinta Vox partbook. The full text in English and German can be found on pp. 255-257. 


\section{Bibliography}

\section{LITERATURE}

Butt, John. Music Education and the Art of Performance in the German Baroque. Cambridge: Cambridge University Press, 1994. https://doi.org/10.1017/CBO9780511597312.

Fisher, Gary. "Renaissance Choral Technique for the Choral Conductor". Choral Journal 29, no. 1 (August 1988): 15-19, 22-23. https://acda.org//files/choral_journals/ August_1988_Fisher_G.pdf.

Grossmann, Burckhard. Anguish of Hell and Peace of Soul: A 1623 Collection of Sixteen Motets on Psalm 116 by Michael Praetorius, Heinrich Schütz and Others. Edited by Christoph Wolff with Daniel R. Melamed. Harvard Publications in Music 18. Cambridge, MA: Harvard University Press, 1994.

Kite-Powell, Jeffery. “German Organ Tablature”. In Encyclopedia of Tablature, edited by John Griffiths. Turnhout: Brepols, forthcoming in 2020.

Lindley, Mark. "Fingering 1". Grove Music Online. 2001; Accessed 18 September 2019. Praetorius, Michael. Syntagma musicum II: De organographia. Wolfenbüttel: Elias Holwein, 1619. Facsimile edition, edited by Wilibald Gurlitt. Documenta musicologica 1, Druckschriften-Faksimiles 14. Kassel: Bärenreiter, 1976.

- Syntagma musicum III, 1619. An online transliteration and critical edition by Christophe Guillotel-Northmann. Thesaurus Musicarum Germanicarum, 2015. http://tmg.huma-num.fr/xtf/view?docId=tei/Praetorius\%201619/Praetorius\%201619. $\mathrm{xml}$; chunk.id=div_2.

_. Syntagma musicum III. Translated and edited by Jeffery Kite-Powell. New York: Oxford University Press, 2004.

\section{Music EDITION}

Grossmann, Burckhard. Anguish of Hell and Peace of Soul: A Collection of Sixteen Motets on Psalm 116 [Angst der Hellen und Friede der Seelen]. Edited by Christoph Wolff with Daniel R. Melamed. Harvard Publications in Music 18. Cambridge, MA: President and Fellows of Harvard College, 1994.

Sound

Angst der Hellen und Friede der Seelen: A Collection of Sixteen Motets on Psalm 116 by Praetorius, Schütz, and others. 2 CDs. Collected by Burckhard Grossman. Alsfelder Vokalensemble, Musica Fiata Köln, Wolfgang Helbich. Recorded 1994, released 1995. Label: CPO 999288 -2. CD 1, track no. 5. 


\section{PRAETORIUSOVA SPREMENLJIVA MNENJA O IZVAJANJU}

\section{Povzetek}

Znano je, da je imel Praetorius svobodne poglede na izvajalske prakse svojega časa. Vedel je, da bo njegovo delo vplivno, obenem pa se je zavedal, da vsak dvor nima tako velikega števila pevcev in inštrumentalistov, kolikor jih je imel sam na voljo v Wolfenbüttlu. Mnogi so jih imeli manj, a želel je vsakovrstnim dvorom ponuditi čim več različnih možnosti izvajanja del za večje sestave.

Razprava se osredotoča na Praetoriusove besede in besedne zveze, ki nakažejo njegov odprti in prilagodljivi pristop do izvajanja lastnih del. Te besede in besedne zveze se nanašajo na število in vrsto glasov, na vrsto in število zborov, na možno izbiro glasbil, ki lahko nadomeščajo druga glasbila, glasove ali zbore, in na to, kako in kje v cerkvi naj bodo zbori postavljeni.

Praetoriusova prilagodljivost glede izvajanja je v nasprotju z nekaterimi drugimi primeri, pri katerih kapelnikom ali izvajalcem ne dopušča nikakršne svobode. Nekaterih praks po njegovem mnenju nikakor ne bi smeli dopustiti. Takšen primer nedopustne prakse je, kadar inštrumentalisti in pevci »tulijo in vreščijo«, da bi preglasili vse druge izvajalce, ter pri tem za pol tona ali še več zvišajo intonacijo.

$\mathrm{V}$ nekaterih drugih primerih pa je Praetorius precej dogmatski, čeprav tudi tam poskrbi za podrobno razlago. Tako na primer pravi, da je $\mathrm{v}$ »motetih in koncertih še posebej ljubko in prijetno, kadar več bolj ekspresivnim in počasnim uvodnim taktom sledi več hitrih fraz«.

Nazadnje - kljub svoji mnogokrat poudarjeni ponižnosti - vendarle pričakuje, da se tudi dugi kapelniki in vodje $\mathrm{z}$ njim strinjajo, kar ponazarja naslednja pripomba: »Vsak razumen glasbenik, ki je pripravljen razmisliti o teh stvareh, mi bo bržkone pritrdil in se strinjal z menoj.«

Podrobnejši pregled teh spremenljivih mnenj nam pomaga bolje razumeti Praetoriusov vpliv na izvajalsko prakso v desetletjih po izidu njegovega dela Syntagma musicum. 